\title{
Phylogeny of the Trichogramma endosymbiont Wolbachia, an alpha-proteobacteria (Rickettsiae)
}

\author{
R. P. Almeida ${ }^{*}$ and R. Stouthamer ${ }^{b}$ \\ ${ }^{a}$ Centro Nacional de Pesquisa de Algodão, Empresa Brasileira de Pesquisa Agropecuária - Embrapa Algodão, CP 174, \\ Campina Grande, PB, Brazil \\ ${ }^{b}$ Department of Entomology, University of California, Riverside, CA 92521, USA \\ *e-mail: raul.almeida@embrapa.br
}

Received: July 15, 2016 - Accepted: January 11, 2017 - Distributed: October 31, 2018

(With 1 figure)

\begin{abstract}
Wolbachia (Hertig) endosymbionts are extensively studied in a wide range of organisms and are known to be transmitted through the egg cytoplasm to the offsping. Wolbachia may cause several types of reproductive modifications in arthropods. In Trichogramma species, parthenogenesis-inducing Wolbachia bacteria allow females wasps to produce daughters from unfertilized eggs and these bacteria are present in at least $9 \%$ of all Trichogramma species. Phylogenetic studies have led to the subdivision of the Wolbachia clade in five supergroups (A, B, C, D and E) and Wolbachia from Trichogramma belong to supergroup B. Here, using the wsp gene, four groups of Wolbachia that infect Trichogramma species were distinguished and the addition of a new group "Ato" was suggested due to the addition of Wolbachia from Trichogramma atopovirilia (Oatman and Platner). Specific primers were designed and tested for the "Ato" group. Seventy-five percent of all evaluated Wolbachia strains from Trichogramma fell within "Sib" group.
\end{abstract}

Keywords: symbiont, egg parasitoid, DNA sequencing, phylogenetic relationships.

\section{Filogenia do endosimbionte Wolbachia em Trichogramma, an alpha-proteobacteria (Rickettsiae)}

\begin{abstract}
Resumo
Endosimbiontes do gênero Wolbachia (Hertig) são extensivamente estudados em uma ampla gama de organismos e são conhecidos por serem transmitidos via citoplasma do ovo hospedeiro para seu descendente. Wolbachia pode causar vários tipos de alterações reprodutivas nos artrópodes. Nas espécies de Trichogramma, a reprodução partenogenética induzida por Wolbachia, possibilita as fêmeas dos parasitoides a produção de fêmeas a partir de ovos não fertilizados e estas bactérias estão presentes em pelo menos $9 \%$ de todas as espécies de Trichogramma. Estudos filogenéticos têm levado a subdivisão do clado Wolbachia em cinco supergrupos (A, B, C, D and E). Wolbachia em Trichogramma pertence ao supergrupo B. Com o gene wsp foi possível se distinguir quatro grupos de Wolbachia que infectam Trichogramma e adicionar um novo grupo (Ato) devido a inclusão de Wolbachia detectada em Trichogramma atopovirilia (Oatman and Platner, 1983). Primers específicos foram construídos e testados para o grupo "Ato". Setenta e cinco por cento de todas as linhagens de Wolbachia que infectam Trichogramma se enquadraram dentro do grupo "Sib".
\end{abstract}

Palavras-chave: simbionte, parasitoide de ovos, sequenciamento de DNA, filogenia.

\section{Introduction}

Wolbachia (Hertig) (Rickettsiaceae) symbionts have been extensively studied in a wide range of organisms and are estimated to be present in over $16 \%$ of insect species infected in Panama (Werren et al., 1995b), in 22\% of British insects (West et al., 1998) and 19.3\% of the temperate North American insects, including the major orders Diptera, Coleoptera, Lepidoptera, Hymenoptera and Orthoptera (Werren and Windsor, 2000).

Wolbachia infects the reproductive tissues of arthropods, are transmitted through the egg cytoplasm and cause

several reproductive modification types: (1) cytoplasmic incompatibility (CI) in insects (Breeuwer and Werren, 1990; Breeuwer et al., 1992; Giordano et al., 1995), isopods (Legrand and Juchault, 1986; Rousset et al., 1992) and mites (Johanowicz and Hoy, 1996; Tsagkarakou et al., 1996).

Cytoplasmic incompatibility results in aborted karyogamy (O’Neill and Karr, 1990) and occurs when infected males are crossed with females that are either uninfected (unidirectional incompatibility) (Hoffmann et al., 1986) or infected with another bacterial variant (bidirectional 
incompatibility); (2) feminization in isopods where genetic males are converted into functional females (Martin et al., 1994; Rousset et al., 1992); (3) the induction of complete parthenogenesis in some haplodiploid species (Almeida and Stouthamer, 2015; Almeida et al., 2010; Stouthamer et al., 1990, 1993). Parthenogenesis-inducing Wolbachia bacteria allow infected female to produce offspring from unfertilized eggs due to a first mitotic division modification (Stouthamer and Kazmer, 1994) and the genetic basis for the loss of female sexual function could be explained by a dominant nuclear effect (Russell and Stouthamer, 2011); (4) fecundity increase of the host for the egg parasitoid Trichogramma bourarachae (Pintureau and Babault, 1980; Vavre et al., 1999b) and (5) male-killing in a wide range of insects. This is a case in which inherited bacteria kill male hosts during early development (Dyson et al., 2002); (6) complete dependence on Wolbachia for egg development (Dedeine et al., 2001).

The phylogeny of Wolbachia has been studied using a number of different genes. (1) the 16S rDNA(Stouthamer et al., 1993); (2) the 23S rDNA (Rousset et al., 1992); (3) the bacterial cell-cycle fts $Z$ gene (Werren et al., 1995a); (4) the spacer-2 region (SR2) which includes the 3' flanking sequences of $23 \mathrm{~S}$ rDNA gene and the major part of $5 \mathrm{~S}$ rDNA gene (Van Meer, 1999); (5) the groE-homologue (Masui et al., 1997); and (6) the wsp gene, that codes for an outer membrane protein of Wolbachia (Braig et al., 1998).

Using the 16S rDNA gene Stouthamer et al. (1993) showed less than 3\% difference between Wolbachia strains despite different reproduction effects that they induce in their hosts. Rousset et al. (1992) reported that the phylogenetic trees produced by $23 \mathrm{~S}$ rDNA and $16 \mathrm{~S}$ rDNA were very similar and the phylogenetic resolution for the $23 \mathrm{~S}$ was similar to that provided by $16 \mathrm{~S}$. Van Meer (1999) found a larger variation by using the SR2 in comparison to $f t s Z$ gene, although the resolution was not improved because of its small size. Higher variation in groE-homologue operon than $f t s Z$ was shown by Masui et al. (1997), but no large sequence data set exists of this gene. The wsp gene also exhibited higher variation than the $f$ ts $Z$ gene with an extensive sequence database available (Zhou et al., 1998).

According to Bourtzis et al. (1998) the wsp gene appeared to result in a closer relationship between the phylogeny of Wolbachia and its reproductive modifications. All Wolbachia strains inducing no CI effect in Drosophila were able to rescue closely related strains that do induce CI. Based on the fts $Z$ gene (Werren et al., 1995a) and wsp gene (Zhou et al., 1998) the Wolbachia clade was subdivided into two groups (A and B) and a maximum sequence difference of $15 \%$ was reported between groups, but this difference was relatively low within group A (3\%) (Werren et al., 1995a). Zhou et al. (1998) distinguished twelve distinct groups based on the grouping criterion of $2.5 \%$ sequence difference of the wsp.

Van Meer et al. (1999) added one new Wolbachia group to the supergroup A and six groups to the supergroup B. Two other supergroups ( $\mathrm{C}$ and $\mathrm{D})$ were found in nematodes (Bandi et al., 1998). The Wolbachia supergroup (E), based on the $16 \mathrm{~S}$ rDNA, was found in Collembola (Vandekerckhove et al., 1999).

In Trichogramma, Schilthuizen and Stouthamer (1997) showed that all Wolbachia strains were monophyletic using a phylogeny based on the fts $Z$ gene and cospeciation of host and symbiont was excluded as an explanation for that phenomenon because the phylogenetic trees of Trichogramma and their Wolbachia were not congruent. In addition, it was suggested that horizontal transmission sometimes occurs inside a common host egg of Trichogramma and this hypothesis was confirmed by Huigens et al. (2000, 2004).

In this work, the phylogeny of the parthenogenesisinducing Wolbachia that infects Trichogramma was studied using the wsp gene.

\section{Material and Methods}

\subsection{Host species of Wolbachia symbiont}

Wolbachia host species, line designation and origin are presented in Table 1. Trichogramma and Wolbachia DNA Extraction, PCR Amplification and Electrophoresis Wolbachia DNA extraction were performed by grinding five Trichogramma females in $100 \mu 15 \%$ Chelex-100 and $4 \mu \mathrm{l}$ proteinase $\mathrm{K}(20 \mathrm{mg} / \mathrm{ml})$, subsequently this mixture is incubated for at least 4 hours at $56^{\circ} \mathrm{C}$, followed by $10 \mathrm{~min}$ at $95{ }^{\circ} \mathrm{C}$. PCR was performed in a total volume of $50 \mu \mathrm{l}$ using a Techne thermocycler, $5 \mu$ DNA template, $5 \mu \mathrm{l}$ PCR-buffer, $1 \mu \mathrm{d}$ dNTP's (each in a $10 \mathrm{mM}$ concentration), $1 \mu 1$ forward and reverse primers; $0.14 \mu 1$ SuperTAQ polymerase (Sphaero-Q 5 units/ $\mu 1$ ) and $36.86 \mu$ l of sterile distilled water.

DNA amplification was done using the specific primers of the $w s p$ region (Braig et al., 1998): wsp-forward: 5' -TGGTCCAATAAGTGATGAAGAAAC-3' and wsp-reverse 5' - AAAAATTAAACGCTACT CCA-3'. The cycling program was $3 \mathrm{~min}$ at $94{ }^{\circ} \mathrm{C}$ followed by 40 cycles of $1 \mathrm{~min}$. at $94{ }^{\circ} \mathrm{C}, 1 \mathrm{~min}$. at $50^{\circ} \mathrm{C}$ and $1 \mathrm{~min}$. at $72{ }^{\circ} \mathrm{C}$ with $5 \mathrm{~min}$ at $72{ }^{\circ} \mathrm{C}$ after the last cycle.

\subsection{Cloning, sequencing and alignments}

Following electrophoresis, PCR products were purified with a QIAquick PCR purification kit (Qiagen $\left.{ }^{\circledR}\right)$. After purification the PCR products were ligated into a Pgem-T ${ }^{\circledR}$ Vector (Promega), $2 \mu 1$ of the ligation mix was used to transform competent cells of DH5- $\alpha$ Escherichia coli using heat shock and plated in a LB agar medium containing Ampicilin, X-GAL and IPTG. The plates were stored overnight at $37{ }^{\circ} \mathrm{C}$. The next day, white colonies were picked with a sterile toothpick from the plates and placed into tubes containing $3.0 \mathrm{ml}$ of LB liquid medium and $3 \mu \mathrm{l}$ Ampicilin and put to grow up overnight in a shaker set to $250 \mathrm{rpm}$ at $37^{\circ} \mathrm{C}$. To confirm that the correct gene had been cloned, a PCR reaction was done using a template extracted from the bacterial culture. This template extraction was done by adding $10 \mu \mathrm{l}$ of the bacterial culture to $100 \mu 15 \%$ Chelex-100, which was incubated for $15 \mathrm{~min}$. at $60^{\circ} \mathrm{C}$ followed by $5 \mathrm{~min}$. at $95^{\circ} \mathrm{C}$. The PCR was performed using $5 \mu \mathrm{l}$ of template in a final volume of 
Table 1. Host species, line designation, origin, GenBank accession numbers and references on the Wolbachia strains.

\begin{tabular}{|c|c|c|c|c|}
\hline Host & $\begin{array}{c}\text { Line } \\
\text { Designation }\end{array}$ & Origin & $\begin{array}{c}\text { Genbank } \\
\text { Acces. Number }\end{array}$ & References \\
\hline L. strialellus & - & - & AF020080 & Zhou et al. (1998) \\
\hline T. confusum & - & - & AF020083 & Zhou et al. (1998) \\
\hline T. bedeguaris & - & - & AF071915 & Van Meer et al. (1999) \\
\hline T. atopovirilia & Tato-01 & Minas Gerais, Brazil & - & This study \\
\hline \multirow[t]{2}{*}{ T. brevicapillum } & - & Mojave desert, CA, USA & - & This study \\
\hline & M & Mojave River Forks & - & This study \\
\hline \multirow[t]{2}{*}{ T. cordubensis } & $28 \mathrm{~A} 63 \mathrm{a}$ & Divor, Portugal & - & This study \\
\hline & - & - & AF245164 & Pintureau et al. (2000) \\
\hline T. dendrolimi & - & - & AB094397 & Tagami et al. (2001) \\
\hline \multirow[t]{2}{*}{ T. deion } & TX & Sanderson, TX & AF020084 & Zhou at al. (1998) \\
\hline & SW436 & Mojave desert, CA, USA & AF071925 & Van Meer et al. (1999) \\
\hline T. embryophagum & Uro3 & Orumiyeh, Iran & AF245165 & Pintureau et al. (2000) \\
\hline T. evanescens & M36 & Alpes-maritimes, France & AF245167 & Pintureau et al. (2000) \\
\hline \multirow[t]{3}{*}{ T. kaykai } & JT6-3 & San Bernardino, CA, USA & AF071924 & Van Meer et al. (1999) \\
\hline & - & $\begin{array}{l}\text { Last Chance Canyon, } \\
\text { Kern Co, CA, USA }\end{array}$ & AF071927 & Van Meer et al. (1999) \\
\hline & $\mathrm{B}$ & - & AF071924 & Van Meer et al. (1999) \\
\hline T. nubilale & 234 & Nova Scotia, Canada & AF071926 & Van Meer et al. (1999) \\
\hline T. oleae & $\mathrm{S} 2$ & Former Yugoslavia & AF245166 & Pintureau et al. (2000) \\
\hline \multirow[t]{7}{*}{ T. pretiosum } & Tpre-03 & Lambayeque, Peru & - & This study \\
\hline & Tpre-04 & Tacna, Peru & - & This study \\
\hline & Tpre-06 & Ica, Peru & - & This study \\
\hline & Tpre-09 & Ayacucho, Peru & - & This study \\
\hline & Tpre-13 & Santa Catarina, Brazil & - & This study \\
\hline & M & Nuevo Leon, Mexico & - & This study \\
\hline & $\mathrm{U}$ & Uruguay & AF245163 & Pintureau et al. (2000) \\
\hline T. semblidis & Semv & $\begin{array}{c}\text { Valbomme, } \\
\text { Alpes-maritimes, France }\end{array}$ & AF145162 & Pintureau et al. (2000) \\
\hline T. sibericum & SIB & Canada & AF071923 & Van Meer et al. (1999) \\
\hline
\end{tabular}

$50 \mu 1$. If indeed the correct gene was cloned, the culture was used in a QIAprep Miniprep kit (Qiagen ${ }^{\circledR}$ ) to purify the plasmid, for the sequencing in an Applied Biosystems automatic sequencer.

\subsection{Phylogenetic analysis}

A total of 27 wsp sequences were used in this study (Table 1). Wolbachia sequences were aligned using the BioEdit sequence editor (Hall, 1999). Analyses were performed using PAUP 4.0b2a (Swofford, 1999) using heuristic search. Successive approximations weighting was done using the rescaled consistency index and a base weight of 1,000 .

Heuristic searches were performed (300 random replicate searches); bootstrap analysis was done with 300 replications. DNADIST program, version $3.5 \mathrm{c}$ was used to compute distance matrix from nucleotide sequences (Hall, 1999). A DNADIST program (version 3.5c) from the BioEdit sequence editor was used to calculate the distance matrix of the wsp sequences.

\section{Results}

Specific primers (wsp) (Braig et al., 1998) were successfully used for the amplification of the Wolbachia strains from the Trichogramma species studied here. The negative control did not result in DNA amplification. Wolbachia phylogeny was built using Wolbachia strains from four Trichogramma species (T. atopovirilia Oatman and Platner; T. pretiosum Riley, 1879; T. cordubensis Vargas and Cabello, 1985 and T. brevicapillum Pinto and Platner, 1978) sequenced in this study, combined with several other strains of the genders Laodelphax, Tribolium, Torymus and Trichogramma ( $=$ T. dendrolimi Matsumura, 1926; T. deion Pinto and Oatman, 1986; T. embryophagum Hartig, 1838; T. evanescens Westwood, 1833; T. kaykai Pinto and Stouthamer, 1997; T. nubilale Ertle and Davis, 1975; T. oleae Voegelé and Pointel, 1979; T. semblidis Aurivillius, 1897 and T. sibericum Sorokina, 1981), obtained from the GenBank (Table 1). The Wolbachia strain that infects T. atopovirilia species was first reported from Brazil by Ciociola Junior et al. (2001). All other 
T. atopovirilia collected so far from several countries (Mexico, El Salvador, Guatemala, Honduras, Colombia, and Venezuela) (Pinto, 1998; Zucchi and Monteiro, 1997) are not infected with the PI Wolbachia.

Six Wolbachia strains from T. pretiosum were studied. The Wolbachia strain obtained from the line Tpre-13 of T. pretiosum was collected in Brazil (Almeida et al., 2001). Four lines (Tpre-03, 04, 06 and 09) were collected in Peru and one from Mexico (M).

According to Van Meer et al. (1999), three groups of Wolbachia that infect Trichogramma were recognised (Dei, Sib and Kay). Pintureau et al. (2000) studying Wolbachia in Trichogramma suggested the creation of a new group (Sem) for T. semblidis and to merge the groups Sib and Kay under the name Sib because after the addition of new hosts, these groups did not differ by $2.5 \%$ any longer.
All Wolbachia strains studied here fell within the groups already known. Two T. pretiosum lines (Tpret-06 and Tpret-13) fell within the group of $T$. deion (Dei) and the three others lines fell within the merged group Sib $(S i b+K a y)$ proposed by Pintureau et al. (2000). In addition, that proposal is in agreement with this study and was confirmed by including many other sequences from the GenBank database (Figure 1). The Wolbachia strains that infect $T$. cordubensis and T. brevicapillum also belong to Sib group. Inclusion of the Wolbachia from T. cordubensis in Sib group agrees with the results obtained by Pintureau et al. (2000). T. brevicapillum was also classified in the same group as T. cordubensis and its classification in the B group was shown by von der Schulenburg et al. (2000) using the $f t s Z$ gene. Wolbachia from T. dendrolimi also fell in the Sib group.

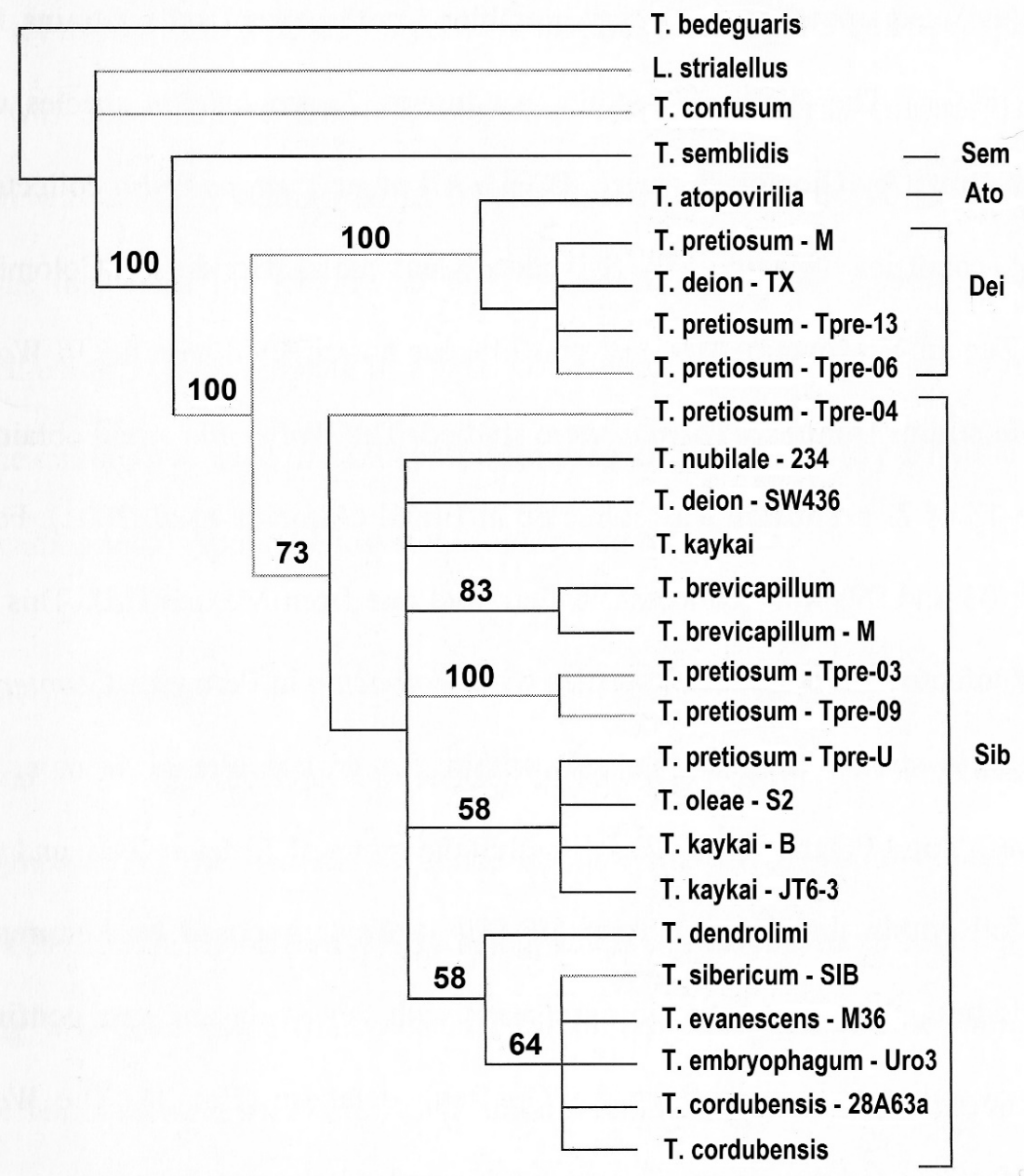

Figure 1. Phylogenetic relationships among Wolbachia strains from different Trichogramma hosts based on wsp gene. Heuristic searches were performed (300 random replicate searches) and Bootstrap values based on 1000 replicate searches with 2 random replicate per search. 


\section{Discussion}

Van Meer et al. (1999) and Pintureau et al. (2000) have found different strains of Wolbachia that infect T. deion species belonging to different groups (Dei and $\mathrm{Sib}$ ). Here the same situation was found for T. pretiosum. The Wolbachia sequence obtained from T. atopovirilia did not fit in any existing groups (Table 2) using a threshold of $2.5 \%$ sequence of divergence (Zhou et al., 1998). The most closely related Wolbachia sequence from $T$. atopovirilia was $T$. pretiosum (line Tpret-13). With this finding, the creation of a new Wolbachia group is proposed under the name "Ato". Thus, the inclusion of this group increased the number of groups of Wolbachia that infect Trichogramma species from three (Pintureau et al., 2000) to four.

Specific primers were designed for Wolbachia found in T. atopovirilia: ATOW-For, 5' -TGCAGCAAATAAAGACAAGGATA-3' and ATOW-Rev, 5' -CCAAAAGTGCCGTAAAGAACA-3'. A specific annealing temperature was used $\left(66^{\circ} \mathrm{C}\right)$. Confirmation of its specificity was done by DNA amplification of T. atopovirilia. Comparison was made with the closest Wolbachia found in T. pretiosum (line Tpre-13) showing that only T. atopovirilia DNA could be amplified. PCR products were loaded on $1 \%$ agarose gel stained with ethidium bromide. Differentiation of these two Wolbachia strains could also be done by restriction analysis using the endonucleases MboI and MboII. The use of the endonuclease $\mathrm{MboI}$ resulted in one cutting site and two restriction fragments (397 and $203 \mathrm{bp}$ ) for T. atopovirilia and two cutting sites and three restriction fragments (266, 203 and $131 \mathrm{bp}$ ) for T. pretiosum. With the enzyme, MboII the cleavage of the DNA product resulted in two cutting sites and three restriction fragments (218, 204 and $76 \mathrm{bp}$ ) for T. atopovirilia and one cutting site and two restriction fragments (318 and $282 \mathrm{bp}$ ) for T. pretiosum.

In 210 described Trichogramma species (Pinto 2006) thelytoky caused by Wolbachia infection has been found in 18 species. It results in all-female broods being usually caused by the cytoplasmically inherited bacterium Wolbachia, which induces gamete duplication in the haplodiploid organisms (Stouthamer and Kazmer, 1994).

Parthenogenesis inducing Wolbachia infecting Trichogramma species are exclusively found in the B supergroup (Pintureau etal., 2000; Poorjavad etal., 2012; Van Meer etal., 1999; Schulenburg et al., 2000; Werren et al., 1995b; Zhou et al., 1998). Several other Wolbachia infections in Trichogramma have been found that belong to the supergroup A, among others the infection in T. bourarachae and T. kaykai (LC110). All these group A Wolbachia sequences are very similar to the Wolbachia found in their laboratory host Ephestia kuehniella (Zeller) (Lepidoptera: Pyralidae), which may indicate that these are either contaminations or are Wolbachia acquired from their hosts (Van Meer et al., 1999; Vavre et al., 1999a).
All Trichogramma species and lines studied here are part of the B group. The Wolbachia strain found in T. atopovirilia is clearly distinct from all others and is therefore put in a new group (Table 2). The specific primers designed in this study will be very useful for distinguishing a possible similar Wolbachia found in T. atopovirilia. The utility of primer specificity in horizontal transmission studies where different hosts are used has been mentioned by Grenier et al. (1998).

Sequences studied here showed a maximum divergence of $10.22 \%$ between Wolbachia strains that infect Trichogramma (Table 2). The Wolbachia variants from different Trichogramma species still form a monophyletic clade when these new species and strains are added.

From all the Wolbachia strains that infect the Trichogramma species eleven belong to the same Wolbachia group (Sib), two fell within Dei group and other two were put individually in one group (Ato and Sem). Similarities in many Wolbachia sequences belonging to a same group as it has been found in Sib group (18 Wolbachia strains) for instance, suggest the possibility of horizontal transfer between different Trichogramma species.

The fact that within Trichogramma species several Wolbachia variants were found indicates that different Wolbachia strains can adapt to specific hosts (Table 1). The cases where natural horizontal transfer was shown so far resulted of Trichogramma species from mixed population (Huigens et al., 2000, 2004). When attempts of horizontal transfer were done using different Trichogramma hosts, as in the case of T. atopovirilia, Wolbachia transmission was not successful (Huigens et al., 2004).

The lack of congruence between the phylogenetic trees of the host species with the Wolbachia tree shown by Schilthuizen and Stouthamer (1997) indicates that horizontal transfer of Wolbachia must have occurred on an evolutionary time scale. Watanabe et al. (2013) suggests studies on Wolbachia transfers between various host combinations to systematically understand the condition of Wolbachia required to express its phenotype, which would contribute to better understanding of Wolbachia-induced host manipulations.

The occurrence of similar Wolbachia retrieved from unrelated hosts confirms the notion that Wolbachia are sometimes transmitted horizontally. However, in many cases, it remains unclear how such transfers could have taken place, because the connection between the species is obscure (Van Meer, 1999). Intraspecific natural horizontal transmission in Trichogramma was reported by Huigens et al. (2000). Interspecific transfer has also been shown (Huigens et al., 2004). Wolbachia transmission has been possible when infected larvae of Trichogramma share a common host with uninfected ones. However, the process by which uninfected Trichogramma larvae acquire Wolbachia remains unclear. 


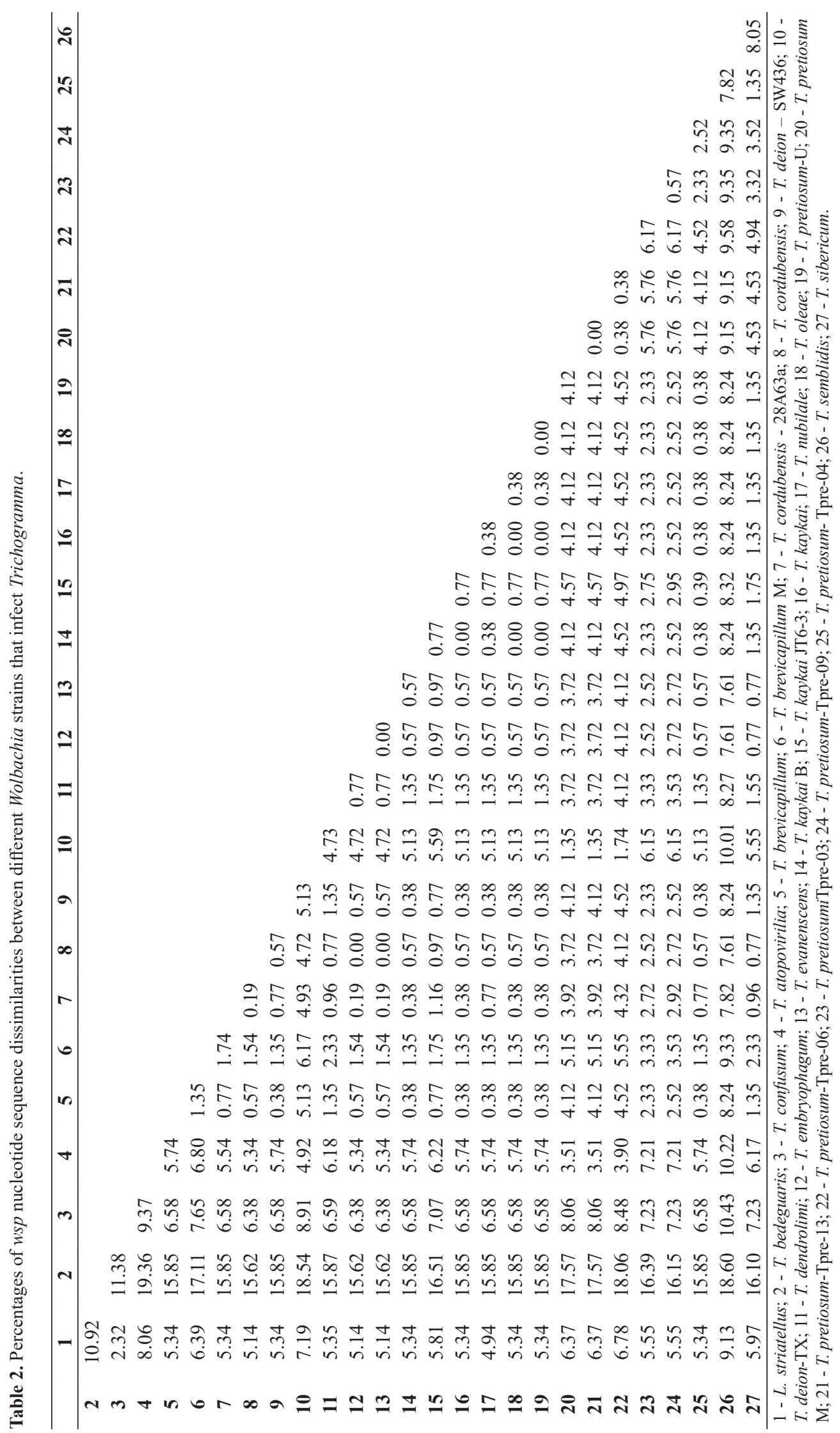




\section{Acknowledgements}

We thank to all those who sent Trichogramma species: Americo I. Ciociola Junior (EPAMIG-Brazil), Isabel M.M.M. Silva (Wageningen University), M.E. Huigens (Wageningen University), and Ranyse B.Q. da Silva (ESALQ-USP-Brazil). This phylogenetic study was financially supported by Embrapa and the Wageningen University Graduate School Production Ecology and Resource Conservation (PE\&RC) (R.P.A).

\section{References}

ALMEIDA, R.P. and STOUTHAMER, R., 2015. ITS-2 sequencesbased identification of Trichogramma species in South America. Brazilian Journal of Biology = Revista Brasileira de Biologia, vol. 75, no. 4, pp. 974-982. PMid:26602337. http://dx.doi. org/10.1590/1519-6984.04614.

ALMEIDA, R.P., CIOCIOLA JUNIOR, A.I. and STOUTHAMER, R., 2001. Wolbachia-induced parthenogenesis: the first report in a Brazilian Trichogramma pretiosum population. Proceedings of the Section Experimental and Applied Entomology of the Netherlands Entomological Society, vol. 12, pp. 41-44.

ALMEIDA, R.P., VAN LENTEREN, J.C. and STOUTHAMER, R., 2010. Does Wolbachia infection affect Trichogramma atopovirilia behaviour? Brazilian Journal of Biology = Revista Brasileira de Biologia, vol. 70, no. 2, pp. 435-442. PMid:20379652. http:// dx.doi.org/10.1590/S1519-69842010005000016.

BANDI, C., ANDERSON, T.J.C., GENCHI, C. and BLAXTER, M.L., 1998. Phylogeny of Wolbachia in Filarial nematodes. Proceedings. Biological Sciences, vol. 265, no. 1413, pp. 24072413. PMid:9921679. http://dx.doi.org/10.1098/rspb.1998.0591.

BOURTZIS, K., DOBSON, S.L., BRAIG, H.R. and O'NEILL, S.L., 1998. Rescuing Wolbachia have been overlooked. Nature, vol. 391 , no. 6670 , pp. 852-553. PMid:9495337. http://dx.doi. org/10.1038/36017.

BRAIG, H.R., ZHOU, W., DOBSON, S.L. and O'NEILL, S.L., 1998. Cloning and characterization of a gene encoding the major surface protein of the bacterial endosymbiont Wolbachia pipientis. Journal of Bacteriology, vol. 180, no. 9, pp. 2373-2378. PMid:9573188.

BREEUWER, J.A.J. and WERREN, J.H., 1990. Microorganisms associated with chromosome destruction and reproductive isolation between two insect species. Nature, vol. 346, no. 6284, pp. 558560. PMid:2377229. http://dx.doi.org/10.1038/346558a0.

BREEUWER, J.A.J., STOUTHAMER, R., BARNS, D.A., PELLETIER, D.A., WEISBURG, W.G. and WERREN, J.H., 1992. Phylogeny of cytoplasmic incompatibility microorganisms in the parasitoid wasp genus Nasonia (Hymenoptera: Pteromalidae) based on 16S ribosomal DNA sequences. Insect Molecular Biology, vol. 1, no. 1, pp. 25-36. PMid:1343772. http://dx.doi. org/10.1111/j.1365-2583.1993.tb00074.x.

CIOCIOLA JUNIOR, J.R., ALEMIDA, R.P.D., ZUCCHI, R.A. and STOUTHAMER, R., 2001. Detecção de Wolbachia em uma população telítoca de Trichogramma atopovirilia Oatman and Platner (Hymenoptera: Trichogrammatidae) via PCR com o primer específico wsp. Neotropical Entomology, vol. 30, no. 3, pp. 489-491. http://dx.doi.org/10.1590/S1519-566X2001000300027.

DEDEINE, F., VAVRE, F., FLEURY, F., LOPPIN, B., HOCHBERG, M.E. and BOULETREAU, M., 2001. Removing symbiotic Wolbachia bacteria specifically inhibits oogenesis in a parasitic wasp. Proceedings of the National Academy of Sciences of the United States of America, vol. 98, no. 11, pp. 6247-6252. PMid:11353833. http://dx.doi.org/10.1073/pnas.101304298.

DYSON, E.A., KAMATH, M.K. and HURST, G.D.D., 2002. Wolbachia infection associated with all female broods in Hypolimnas bolina (Lepidoptera: Nymphalidae): Evidence for horizontal transmission of a butterfly male killer. Heredity, vol. 88, no. 3, pp. 166-171. PMid:11920117. http://dx.doi.org/10.1038/ sj.hdy.6800021.

GIORDANO, R., O'NEILL, S.L. and ROBERTSON, H.M., 1995. Wolbachia infections and the expression of cytoplasmic incompatibility in Drosophiia sechellia and D. mauritiana. Genetics, vol. 140, no. 4, pp. 1307-1317. PMid:7498772.

GRENIER, S., BERNARD, P., HEDDI, A., LASSABLIERE, F., JAGER, C., LOUIS, C. and KHATCHADOURIAN, C., 1998. Successful horizontal transfer of Wolbachia symbionts between Trichogramma wasps. Proceedings. Biological Sciences, vol. 265, no. 1404, pp. 1441-1445. http://dx.doi.org/10.1098/rspb.1998.0455.

HALL, T., 1999 [accessed 15 July 2016]. Biological sequence alignment editor for Windows 95/98/NT. BioEdit v5.0.9 program [software]. Available from: http://www.mbio.ncsu.edu/BioEdit/ bioedit.html

HOFFMANN, A.A., TURELLI, M. and SIMMONS, G.M., 1986. Unidirectional incompatibility between populations of Drosophila simulans. Evolution; International Journal of Organic Evolution, vol. 40, no. 4, pp. 692-701. PMid:28556160. http:// dx.doi.org/10.1111/j.1558-5646.1986.tb00531.x.

HUIGENS, M.E., ALMEIDA, R.P., BOONS, P.A.H., LUCK, R.F. and STOUTHAMER, R., 2004. Natural interspecific and intraspecific horizontal transfer of parthenogenesis-inducing Wolbachia in Trichogramma wasps. Proceedings. Biological Sciences, vol. 271, no. 1538, pp. 509-515. PMid:15129961. http:// dx.doi.org/10.1098/rspb.2003.2640.

HUIGENS, M.E., LUCK, R.F., KLAASSEN, R.H.G., MAAS, M.F.P.M., TIMMERMANS, M.J.T.N. and STOUTHAMER, R., 2000. Infectious parthenogenesis. Nature, vol. 405 , no. 6783 , pp. 178-179. PMid:10821272. http://dx.doi.org/10.1038/35012066.

JOHANOWICZ, D.L. and HOY, M.A., 1996. Molecular evidence for a Wolbachia endosymbiont in the predatory mite Metaseiulus occidentalis. Annals of the Entomological Society of America, vol. 89, pp. 435-441. http://dx.doi.org/10.1093/aesa/89.3.435.

LEGRAND, J.J. and JUCHAULT, P., 1986. Rôle de bactéries symbiotiques dans l'intersexualité, la monogénie et la spéciation chez des Crustacés Oniscoïdes. Bollettino di Zoologia, vol. 53, no. 2, pp. 161-172. http://dx.doi.org/10.1080/11250008609355500.

MARTIN, G., GRUPPE, S.G., LAULIER, M., BOUCHON, D., RIGAUD, T. and JUCHAULT, P., 1994. Evidence for Wolbachia spp. in the estuarine isopod Spaeroma rugicauda (Crustacea): a likely cytoplasmic sex ratio distorter. Endocytobiosis and Cell Research, vol. 10, pp. 215-225.

MASUI, S., SASAKI, T. and ISHIKAWA, H., 1997. GroEHomologous operon of Wolbachia, an intracellular symbiont of arthropods: a new approach for their phylogeny. Zoological Science, vol. 14, no. 4, pp. 701-706. PMid:9401467. http://dx.doi. org/10.2108/zsj.14.701.

O'NEILL, S.L. and KARR, T.L., 1990. Bidirectional incompatibility between conspecific populations of Drosophila simulans. Nature, vol. 348, no. 6297, pp. 178-180. PMid:2234083. http://dx.doi. org/10.1038/348178a0.

PINTO, J.D., 1998. Systematics of the North American species of Trichogramma (Hymenoptera: Trichogrammatidae). Washington: 
Allen Press. 287 p. Memoirs of the Entomological Society of Washington, no. 22.

PINTO, J.D., 2006. A review of the New World genera of Trichogrammatidae (Hymenoptera). Journal of Hymenoptera Research, vol. 15, pp. 38-163.

PINTUREAU, B. and BABAULT, M., 1980. Comparaison des estérases chez 19 souches de Trichogrammai (Hym., Trichogramma appartenat au groupe d'espèces evanescens. Archives de Zoologie Expérimentale et Générale, vol. 121, pp. 249-260.

PINTUREAU, B., CHAUDIER, S., LASSABLIÈRE, F., CHARLES, H. and GRENIER, S., 2000. Addition of $w s p$ sequences to the Wolbachia phylogeny tree and stability of the classification. Journal of Molecular Evolution, vol. 51, no. 4, pp. 374-377. PMid:11040288. http://dx.doi.org/10.1007/s002390010099.

POORJAVAD, N., GOLDANSAZ, S.H., MACHTELINCKX, T., TIRRY, L., STOUTHAMER, R. and VAN LEEUWEN, T., 2012. Iranian Trichogramma: ITS2 DNA characterization and natural Wolbachia infection. BioControl, vol. 57, no. 3, pp. 361-374. http://dx.doi.org/10.1007/s10526-011-9397-z.

ROUSSET, F., BOUCHON, D., PINTUREAU, B., JUCHAULT, P. and SOLIGNAC, M., 1992. Wolbachia endosymbionts responsible for various sexual alterations of sexuality in arthropods. Proceedings. Biological Sciences, vol. 250, no. 1328, pp. 91-98. PMid:1361987. http://dx.doi.org/10.1098/rspb.1992.0135.

RUSSELL, J.E. and STOUTHAMER, R., 2011. The genetics and evolution of obligate reproductive parasitism in Trichogramma pretiosum infected with parthenogenesis-inducing Wolbachia. Heredity, vol. 106, no. 1, pp. 58-67. PMid:20442735. http:// dx.doi.org/10.1038/hdy.2010.48.

SCHILTHUIZEN, M. and STOUTHAMER, R., 1997. Horizontal transmission of parthenogenesis inducing microbes in Trichogramma wasps. Proceedings. Biological Sciences, vol. 264, no. 1380, pp. 361-366. PMid:9107051. http://dx.doi.org/10.1098/rspb.1997.0052.

SCHULENBURG, J.H.G., VON DER HURST, G.D.D., HUIGENS, M.E., VAN MEER, M.M.M., JIGGINS, F.M. and MAJERUS, M.E.N., 2000. Molecular evolution and phylogenetic utility of Wolbachia fts $Z$ and wsp gene sequences with special reference to the origin of Male killing. Molecular Biology and Evolution, vol. 17, no. 4, pp. 584-600. PMid:10742050. http://dx.doi.org/10.1093/ oxfordjournals.molbev.a026338.

STOUTHAMER, R. and KAZMER, D.J., 1994. Cytogenetics of microbe-associated panthenogenesis and its consequences for gene flow in Trichogramma wasps. Heredity, vol. 73, no. 3, pp. 317-327. http://dx.doi.org/10.1038/hdy.1994.139.

STOUTHAMER, R., BREEUWERT, J.A.J., LUCK, R.F. and WERREN, J.H., 1993. Molecular identification of microorganisms associated with parthenogenesis. Nature, vol. 361 , no. 6407 , pp. 66-68. PMid:7538198. http://dx.doi.org/10.1038/361066a0.

STOUTHAMER, R., PINTO, J.D., PLATNER, G.R. and LUCK, R.F., 1990. Taxonomic status of thelytokous forms of Trichogramma. Annals of the Entomological Society of America, vol. 83, no. 3, pp. 475-581. http://dx.doi.org/10.1093/aesa/83.3.475

SWOFFORD, D., 1999. PAUP 4.0b2a: computer program distributed. Sunderland: Sinauer Associates.

TAGAMI, Y., MIURA, K. and STOUTHAMER, R., 2001. How does infection with parthenogenesis inducing Wolbachia reduce the fitness of Trichogramma? Journal of Invertebrate Pathology, vol. 78, no. 4, pp. 267-271. PMid:12009809. http:// dx.doi.org/10.1006/jipa.2002.5080.

TSAGKARAKOU,A., GULLLEMAUD, T., ROUSSET, F. and NAVAJAS, M., 1996. Molecular identification of a Wolbachia endosybiont in a Tetranychus urticae strain (Acari: Tetranychidae). Insect Molecular Biology, vol. 5, no. 3, pp. 217-221. PMid:8799741. http://dx.doi.org/10.1111/j.1365-2583.1996.tb00057.x.

VAN MEER, M.M.M., 1999. Phylogeny and host-symbiont interactions of thelytokous inducing Wolbachia in Hymenoptera. Wageningen: Wageningen Agricultural University, 118 p. Ph.D. Thesis.

VAN MEER, M.M.M., WITTEVELDT, J. and STOUTHAMER, R., 1999. Phylogeny of the arthropod endosymbiont Wolbachia based on the wsp gene. Insect Molecular Biology, vol. 8, no. 3, pp. 399-408. PMid:10469257. http://dx.doi.org/10.1046/j.13652583.1999.83129.x.

VANDEKERCKHOVE, T., WATTEYNE, S., WILLEMS, A., SWINGS, J.G., MERTENS, J. and GILLIS, M., 1999. Phylogenetic analysis of the 16S rDNA of the cytoplasmic bacterium Wolbachia from the novel host Folsomia candida (Hexapoda, Collembola) and its implications for wolbachial taxonomy. FEMS Microbiology Letters, vol. 180, no. 2, pp. 279-286. PMid:10556723. http:// dx.doi.org/10.1111/j.1574-6968.1999.tb08807.x.

VAVRE, F., FLEURY, F., LEPETIT, D., FOUILLET, P. and BOULÉTREAU, M., 1999a. Phylogeny evidence for horizontal transmission of Wolbachia in host-parasitoid associations. Molecular Biology and Evolution, vol. 16, no. 12, pp. 17111723. PMid:10605113. http://dx.doi.org/10.1093/oxfordjournals. molbev.a026084.

VAVRE, F., GIRIN, C. and BOULÉTREAU, M., $1999 \mathrm{~b}$. Phylogenetic status of a fecundity-enhancing Wolbachia that does not induce thelytoky in Trichogramma. Insect Molecular Biology, vol. 8, no. 1, pp. 67-72. PMid:9927175. http://dx.doi. org/10.1046/j.1365-2583.1999.810067.x.

WATANABE, M., KAGEYAMA, D. and MIURA, K., 2013. Transfer of a parthenogenesis-inducing Wolbachia endosymbiont derived from Trichogramma dendrolimi into Trichogramma evanescens. Journal of Invertebrate Pathology, vol. 112, no. 1, pp. 83-87. PMid:23063745. http://dx.doi.org/10.1016/j.jip.2012.09.006.

WERREN, J.H. and WINDSOR, D.M., 2000. Wolbachia infection frequences in insects: evidence of a global equilibrium? Proceedings. Biological Sciences, vol. 267, no. 1450, pp. 1277 1285. PMid:10972121. http://dx.doi.org/10.1098/rspb.2000.1139.

WERREN, J.H., WINDSOR, D.M. and GUO, L.R., 1995a. Distribution of Wolbachia among neotropical arthropods. Proceedings of the Royal Society of London B, vol. 262, no. 1364, pp. 197-204. http://dx.doi.org/10.1098/rspb.1995.0196.

WERREN, J.H., ZHANG, W. and GUO, L.R., 1995b. Evolution and phylogeny of Wolbachia: reproductive parasites of arthropods. Proceedings. Biological Sciences, vol. 261, no. 1360, pp. 55-71. PMid:7644549. http://dx.doi.org/10.1098/rspb.1995.0117.

WEST, S.A., COOK, J.M., WERREN, J.H. and GODFRAY, C.J., 1998. Wolbachia in two insect host parasitoid communities. Molecular Ecology, vol. 7, no. 11, pp. 1457-1465. PMid:9819901. http://dx.doi.org/10.1046/j.1365-294x.1998.00467.x.

ZHOU, W., ROUSSET, F. and O’NEIL, S.L., 1998. Phylogeny and PCR-based classification of Wolbachia strains using wsp gene sequences. Proceedings. Biological Sciences, vol. 265, no. 1395, pp. 509-515. PMid:9569669. http://dx.doi.org/10.1098/ rspb.1998.0324.

ZUCCHI, R.A. and MONTEIRO, R.C., 1997. O gênero Trichogramma na América do Sul. In: J.R.P. PARRA and R.A. ZUCCHI, eds. Trichogramma e o controle biológico aplicado. Piracicaba: FEALQ, pp. 41-66. 